\title{
Healthy together Victoria and childhood obesity-a methodology for measuring changes in childhood obesity in response to a community-based, whole of system cluster randomized control trial
}

Claudia Strugnell ${ }^{1 *}$, Lynne Millar ${ }^{1,2}$, Andrew Churchill ${ }^{3}$, Felice Jacka ${ }^{4,5,6,7}$, Colin Bell ${ }^{1,8}$, Mary Malakellis ${ }^{1}$, Boyd Swinburn ${ }^{1,9}$ and Steve Allender ${ }^{1,2}$

\begin{abstract}
Background: Healthy Together Victoria (HTV) - a complex 'whole of system' intervention, including an embedded cluster randomized control trial, to reduce chronic disease by addressing risk factors (physical inactivity, poor diet quality, smoking and harmful alcohol use) among children and adults in selected communities in Victoria, Australia (Healthy Together Communities).

Objectives: To describe the methodology for: 1) assessing changes in the prevalence of measured childhood obesity and associated risks between primary and secondary school students in HTV communities, compared with comparison communities; and 2) assessing community-level system changes that influence childhood obesity in HTC and comparison communities.

Methods: Twenty-four geographically bounded areas were randomized to either prevention or comparison (2012). A repeat cross-sectional study utilising opt-out consent will collect objectively measured height, weight, waist and self-reported behavioral data among primary [Grade 4 (aged 9-10y) and Grade 6 (aged 11-12y)] and secondary [Grade 8 (aged 13-14y) and Grade 10 (aged 15-16y)] school students (2014 to 2018). Relationships between measured childhood obesity and system causes, as defined in the Foresight obesity systems map, will be assessed using a range of routine and customised data.
\end{abstract}

Conclusion: This research methodology describes the beginnings of a state-wide childhood obesity monitoring system that can evolve to regularly inform progress on reducing obesity, and situate these changes in the context of broader community-level system change.

Keywords: Evaluation, Systems, Community-based interventions

\footnotetext{
* Correspondence: claudia.strugnell@deakin.edu.au

'World Health Organization's Collaborating Centre for Obesity Prevention,

Deakin Population Health, Deakin University, Geelong, Australia

Full list of author information is available at the end of the article
} 


\section{Background}

Childhood obesity immediately and distally impacts physical and psychological health [1,2]. The stubbornly high prevalence of obesity globally [3], and persistence of childhood obesity into adulthood [2, 4], with resultant increased morbidity and mortality [5], highlights the imperative to develop effective prevention and monitoring strategies for childhood obesity.

Evidence [6-8] of success in preventing childhood obesity $[6,7]$ in a variety of specific settings (e.g., schoolbased [8-10], community-based [11], home-based [12],) is tempered by challenges in sustaining the long-term impact of these interventions and applying the interventions at the population level [6]. The most recent Cochrane review of obesity prevention [6] has identified that multifaceted and multilevel strategies are required to prevent obesity. The Foresight Obesity Systems Map [13] provides corroboration for this assessment through the visualization of obesity as a complex systems problem [14]. Support is growing for population level efforts to prevent childhood obesity to apply systems thinking [15] in the expectation that systems thinking may improve intervention implementation, effectiveness and sustainability of changes. To date, no known initiative has applied a 'whole of systems' approach to prevent childhood obesity [16]. Healthy Together Victoria's (HTV) large-scale complex whole of system approach to the primary prevention of chronic disease, in the state of Victoria, Australia is a world first. Taking a population-level approach to reducing chronic disease and specifically obesity through improving associated determinants (physical inactivity, poor diet quality, smoking and harmful alcohol use) among children and adults in the specific communities where they "live, learn, work and play" [17]. Due to the broad scope and the adaptive nature of HTV, detailed methods are beyond the remit of this article but can be found at http://www.healthytogether.vic.gov.au/ resources/index.

Commencing in 2012, HTV's multi-faceted intervention includes a boosted capacity at the local level of $>170$ staff in 12 communities [18]. These personnel were employed to support and deliver 'system activation' for healthy environments and healthy living in schools, early childhood settings, workplaces and communities through a variety of means. Systems activation refers to initiating actions on the systems that influence the health and well-being of individuals, families and communities. These actions include delivering multiple strategies, policies and initiatives at both the state and local levels to target all Victorians. Complementing the state-wide systems activation and programs, HTV also contributes resources and effort towards improving the health of children through a quality framework to support the creation of healthier school environments through a range of services such as the Healthy Together Victoria Achievement Program and Healthy Eating Advisory Service and is complemented by a range of community based healthy living programs and state-wide and local social marketing of health promotion messages.

HTV includes a cluster randomized trial of the "whole-ofsystem' intervention. With increasing intervention complexity, evaluation approaches require a degree of flexibility in order to accordingly engage with complexity. In this paper, we outline the methodological approaches that will be taken to comprehensively measure the impacts of HTV on childhood obesity through two parallel research programs with the following aims:

1. To measure the impacts of HTV on anthropometry and obesogenic behaviors among Victorian children and the environments in which they live, learn and play

2. To measure the effects of change to community-level system factors on rates of childhood obesity among Victorian children.

\section{Methods/design \\ Setting}

Healthy Together Victoria, an initiative of the State Government of Victoria, was initially funded in partnership with the Commonwealth Government of Australia [17]. Victoria is a state of approximately 5.8 million people in the SouthEastern region of Australia [19]. As described above, the centrepiece of HTV is a funded workforce of approximately 170 people across the state in local government, community health and non-government organisations whom take a range of actions at the community and state level [18]. These actions are varied but can include: policy and leadership for health promotion; providing quality improvement frameworks for early childhood services, schools and workplaces; supporting policy development/implementation and targeted strategies within settings; working with food growers, producers and sellers to increase access to healthy food, especially disadvantaged populations; working with urban planning to support active transport; working with sport and recreation centres to increase healthy food access; building leadership for prevention; and social marketing of health promotion messaging www.healthytogether.vic.gov.au [18]. The cluster randomized trial, embedded within the wider HTV initiative, includes 12 prevention areas spread across 14 local government authority (LGAs) (Healthy Together Communities) and 11-matched comparison areas spread across 12 LGA's in Victoria, Australia (with one comparison community acting as a matched comparator for two prevention areas). Matched randomisation of clusters was based on socio-demographic indices [Socioeconomic Index for Areas (SEIFA)] [20] and chronic disease risk factor prevalence (i.e., unhealthy weight)] of adults within participating LGA's and was conducted by the Department of Health and Human Services (Victoria). The wider HTV 
evaluation has a multitude of components, several of which are outlined in Table 2. The methodology described here captures (1) how the core primary and secondary outcomes will be measured and (2) how these relate to communitylevel system change.

\section{Research plan aim 1: to measure the impacts of HTV on anthropometry and obesogenic behaviors among Victorian children and the environments in which they live, learn, and play \\ Under aim one it is hypothesized that:}

1) School children in intervention LGAs compared with those in comparison LGAs will record relative decreases in BMI z-scores of at least 0.18 over the measurement period,

2) The prevalence of overweight/obesity among school children in intervention LGAs will decrease over the intervention period, compared to those in the comparison LGAs, and

3) The levels of physical activity will increase, sedentary behavior will decrease and diet quality will improve over the intervention period among school children in the intervention LGAs compared with those in the comparison LGAs.

\section{Study design, sampling and sample size}

Standard approaches for sample size calculations within cluster randomized trials were made (in GenStat V14.2) based on the comparison of Body Mass Index standardized for age and sex (BMI-z) [21] scores between intervention (12 clusters) and comparison (12 clusters) communities using power of 0.8 and 0.05 for significance test. The clustered trial involves intervention at the area level and thus an intra-class correlation of 0.1 for the BMI-z was used, based on previous school-based research [22-24]. Baseline BMI-z $(0.65)$ and standard deviation (0.93) were taken from our previous studies of $>1800$ [22] school children and the expected change in BMI-z over the 4 years was set to 0.18 . The justification for this estimated change over 4 years of 0.18 is based on the findings from our previous interventions within the same age groups (primary [22] and secondary students [24]) and was associated with a 3 percentage point reduction in overweight and obesity in these populations.

Using the parameters above, the sample size calculations indicated a need for $\geq 25$ children in each of the 4 year levels (Grade 4, Grade 6, Grade 8 \& Grade 10) to be assessed in each intervention/comparison area to determine significant differences in BMI-z score between intervention and comparison communities. A repeat crosssectional design will assess all participating students in each grade level per intervention and comparison community and repeated samples of students on a biennial basis in 2014, 2016 and 2018 during Term 3 (Jul - Sept) of the Victorian School Term (giving a total of approximately $>7,200$ children assessed once).

\section{School and participant recruitment}

A list of all Victorian schools will be stratified by LGA and a random sampling technique with replacement used to invite three primary and three secondary schools within each of the prevention and control areas (spanning 26 LGAs). For example, should all schools that have been selected at random decline to participate, then the next three schools selected at random will be invited. Written invitations will be sent to the school Principal with follow-up phone calls, emails and/or visits used to confirm participation. All students in Grade 4 and Grade 6, or Grade 8 and Grade 10, will be invited to voluntarily participate through the distribution of the plain language statement and opt-out consent form. An opt-out recruitment procedure will be used, whereby participants are only required to return a signed opt-out form if they or their parents/guardians do not want their child to participate. However, if an individual child does not wish to be measured or surveyed they do not have to participate, regardless of having a signed opt-out consent form. This study has been approved by Deakin University's Human Research Ethics Committee (2013-095), the Victorian Department of Education and Training (2013_002013) and the Catholic Archdiocese of Melbourne, Sandhurst, Ballarat and Sale.

\section{Study protocol and procedures}

Approximately 10 weeks are allocated for the recruitment of schools and participants in Term 2 (April-June) and 10 weeks for the collection of data during Term 3 in each study year. Consenting participants will be invited to complete a self-report questionnaire and have their height, weight and waist circumference measured (see Table 1). All measurements will be conducted throughout the school day by trained research staff using calibrated equipment and is expected to take between $20-30 \mathrm{~min}$ to complete the questionnaire and 3-5 min to complete anthropometric measures.

\section{Measures \\ Primary outcome}

Anthropometry: height weight and waist circumference Height will be measured to the nearest $0.1 \mathrm{~cm}$ using a portable stadiometer (Charder HM-200P Portstad, Charder Electronic Co Ltd, Taichung City, Taiwan) and weight to the nearest $0.1 \mathrm{~kg}$ using an electronic weight scale (A\&D Precision Scale UC-321; A7D Medical, San Jose, CA) without shoes and whilst wearing a light layer of clothing (e.g., shirt/t-shirt and shorts/long pants/skirt). Age and sexspecific body mass index (BMI) z-scores will be calculated 
Table 1 Primary and secondary outcomes of interests and proposed instrument/measure

\begin{tabular}{|c|c|c|}
\hline Item & Outcome(s) of interest & Proposed Instrument/measure \\
\hline Anthropometry & $\begin{array}{l}\text { - Change in BMI-z score } \\
\text { - Change in overweight and obesity prevalence } \\
\text { - Change in abdominal obesity prevalence }\end{array}$ & Height, weight \& waist circumference \\
\hline $\begin{array}{l}\text { Physical activity and Sedentary } \\
\text { behavior }\end{array}$ & \multirow{2}{*}{$\begin{array}{l}\left.\text { - Change in minutes per day (mins. } .^{-1}\right) \text { spent } \\
\text { in daily moderate-to-vigorous physical activity } \\
\text { (MVPA) and sedentary time } \\
\text { - Change in the proportion of participants } \\
\text { meeting Australia's physical activity and sedentary } \\
\text { behavior guidelines for children (5-12 years) [33] } \\
\text { and young people (13-17 years) [34] } \\
\text { - Change in levels of perceived psychosocial } \\
\text { influences on physical activity participation }\end{array}$} & \multirow{2}{*}{$\begin{array}{l}\text { Modified questionnaire containing } \\
\text { items from the Core Indicators and } \\
\text { Measures of Youth Health [30] and } \\
\text { SHAPES [28] surveys. }\end{array}$} \\
\hline $\begin{array}{l}\text { Duration, intensity and perceived } \\
\text { psychosocial influences }\end{array}$ & & \\
\hline Diet & \multirow[b]{2}{*}{$\begin{array}{l}\text { - Change in typical/usual serves of fruit and } \\
\text { vegetable daily } \\
\text { - Change in typical/usual serves of non-core foods } \\
\text { - Change in typical/usual serves of sugar-sweetened } \\
\text { beverages } \\
\text { - Change in the proportion of participants meeting } \\
\text { the Australian Dietary guidelines for fruit and } \\
\text { vegetable intakes [38] } \\
\text { - Change in usual caffeinated energy drink intake }\end{array}$} & \multirow[b]{2}{*}{$\begin{array}{l}\text { Modified version of the Simple } \\
\text { Dietary Questionnaire (Parletta N, } \\
\text { Frensham L, Peters J , O'Dea K, } \\
\text { Itsiopoulos C. Validation of a Simple } \\
\text { Dietary Questionnaire with } \\
\text { adolescents in an Australian population, } \\
\text { unpublished). [56] }\end{array}$} \\
\hline Type, frequency & & \\
\hline Moods and Feelings & \multirow[t]{2}{*}{ - Change in depressive symptom score } & \multirow{2}{*}{$\begin{array}{l}\text { Grade 8-10: Short Moods and Feelings } \\
\text { Questionnaire [47] }\end{array}$} \\
\hline Emotional wellbeing & & \\
\hline Quality of Life & $\begin{array}{l}\text { - Change in the global score } \\
\text { - Change in psychosocial health summary score } \\
\text { - Change in physical health summary score }\end{array}$ & $\begin{array}{l}\text { Paediatric Quality of Life Inventory } \\
\text { (PedsQL) [40] }\end{array}$ \\
\hline Environments & $\begin{array}{l}\text { - Change in school policy environment } \\
\text { - Change in school physical environment } \\
\text { - Change in school economic environment } \\
\text { - Change in school socio-cultural environment }\end{array}$ & $\begin{array}{l}\text { Primary Schools: Be Active Eat Well } \\
\text { Environment questionnaireSecondary } \\
\text { schools: It's Your Move Environment } \\
\text { Questionnaire }\end{array}$ \\
\hline
\end{tabular}

using the World Health Organizations' growth reference to categorize weight status [21]. Waist circumference will be taken over light clothing using the cross-over technique at the midway point between the lower costal border $\left(10^{\text {th }}\right.$ rib) and the top of the iliac crest, in the mid-axillary line, perpendicular to the long axis of the trunk [25] using a steel tape measure (Lufkin W606PM) to the nearest $0.1 \mathrm{~cm}$. Waist circumference data will be used to examine abdominal obesity when mean waist circumference is greater than the 90th percentile [26] according to the International Diabetes Federation using the British age and sex-specific growth reference [27]. Two measurements will be taken for height, weight and waist and the average calculated unless a third measure be needed when a discrepancy of $0.5 \mathrm{~cm}$ for height and waist and $0.5 \mathrm{~kg}$ for weight occurs.

\section{Secondary outcomes}

Physical activity and sedentary behavior: questionnaire After evaluating current tools to examine self-reported physical activity and sedentary behavior among youth, the School Health Action, Planning and Evaluation System (SHAPES) questionnaire was identified as an exemplar as it had previously demonstrated moderate construct validity correlations (accelerometry) for average Moderate-to-Vigorous Physical Activity (MVPA) min. $\mathrm{d}^{-1}(r=0.44, P<0.01)$ among Grade 4 to Grade 10 Canadian children [28]. This construct validity correlation is considerable given that a recent systematic review of physical activity questionnaires found median criterion validity correlations to be $r=0.30$ to 0.39 for new questionnaires and $r=0.25$ to 0.41 for existing questionnaires [29]. The authors of the SHAPES questionnaire were contacted and they highlighted success towards uniform/standard measurement of physical activity and sedentary behavior across Canada (in consultation with several other universities) [30]. The use of standard measures potentially enables comparisons with other studies. Therefore, three question items from the standardised Canadian Core Indicators and Measures of Youth Health - Physical Activity \& Sedentary Behavior Module [30] questionnaire examining duration spent in MVPA, sedentary behavior and mode of active transport to and from school were also included alongside 15 question items from the SHAPES questionnaire examining active transport, frequency of physical education and perceived psychosocial influences on physical activity (social support and parental modelling) [28]. The SHAPES questionnaire and Core Indicators and Measures were developed in Canada and based on the Canadian physical 
activity [31] and sedentary behavior [32] guidelines for youth. These guidelines are identical to the Australian physical activity and sedentary behavior guidelines in recommending $\geq 60 \mathrm{~min} /$ day of MVPA and $\leq 2 \mathrm{~h} /$ day of electronic media for entertainment [33, 34]. This supports the use of these question items in the Australian context as they are likely to have similar psychometric properties among Australian youth. Through these questionnaires, duration spent in MVPA (in total) and sedentary behavior (outside of school) over the previous 7 days will be recalled by participants and adherence to Australia's physical activity and sedentary behavior guidelines for children (5-12 years) [33] and young people (13-17 years) [34] calculated. Contextual information relating to participation (e.g., number of television units in house and active transportation) and perceived psychosocial influences on physical activity participation (e.g., social support, parental modelling) will also examined.

\section{Diet quality: questionnaire}

Self-reported usual dietary intake is commonly examined through food frequency questionnaires at the population level as they are quick to complete, inexpensive and have low participant burden in large scale studies [35]. The advantage of a food frequency questionnaire compared to a $24 \mathrm{~h}$ diet recall questionnaire is that usual intake can be estimated, whereas a singular $24 \mathrm{~h}$ diet recall is subject to intra-individual variation and requires several administrations to capture usual intake, which subsequently increases costs and subject burden [35]. The Simple Dietary Questionnaire (SDQ) was selected to examine dietary behaviors as it has been validated among Australian school children aged 13 to 16 years and demonstrated moderate validity correlations $(r=0.42$ to $0.57)$ for fruit and vegetable intake with $24 \mathrm{~h}$ diet recall (Parletta N, Frensham L, Peters J , O’Dea K, Itsiopoulos C. Validation of a Simple Dietary Questionnaire with adolescents in an Australian population, unpublished). In comparison, a recent systematic review of food frequency questionnaires among youth found validity correlations ranged from $r=0.1$ to 0.8 [36], further supporting the use of the SDQ in the current study. The SDQ is a quick to complete 27-items questionnaire that examines intakes of fruit and vegetables, dairy (milk, cheese, ice-cream), sweetened beverages and non-core foods (e.g., takeaway food and candy) and was based on the former (2003) Australian dietary guidelines [37]. The number of fruit and vegetable serves usually eaten each day will be specifically examined to detect changes in the proportions of participants adhering to the current Australian Dietary Guidelines for daily serves of fruit and vegetables and the questionnaire was amended to allow for half-serves to be recorded for fruit and vegetable consumption (e.g., 1 serve, 1.5 serves, 2 serves... etc.) [38].
In addition, intakes of core and non-core foods and beverages will be examined for changes over time.

\section{Quality of life: questionnaire}

Given that childhood obesity has both physical and psychological health consequences [1, 2], the assessment of health-related quality is important to capture the multidimensional state of health [39]. Although quality of life is a complex concept, a critical search of the literature supported the use of the Paediatric Quality of Life Inventory 4.0 (PedsQL) ${ }^{\mathrm{mm}}[40]$ to examine perceived healthrelated quality of life among participants. The PedsQL has been widely used in Australian [41-44] and international (>350 citations in Medline) studies of children and adolescents to examine health-related quality of life in a variety of settings, thus enabling accurate comparison to other studies due to the application of the same instrument. It is a quick to complete (1-page) 23-item questionnaire that examines self-rated physical health, emotional health, school functioning and social health. It has been subject to extensive psychometric testing in a variety of languages [45] with high internal consistency observed among children 8 to 11 years $(\alpha=0.90-0.91)$ in the United States and validity through comparison with children with diagnosed chronic health conditions (effect size $d=0.63-0.72$ ) [40]. The questionnaire includes four domains (physical health, emotional health, school functioning and social health) that will be examined individually and in combination both cross-sectionally and change over time. The scores are summed to provide an overall global health-related quality of life score as well as generating physical and psychosocial sub-scale scores.

\section{Depressive symptomology: questionnaire (Grade 8 and Grade 10)}

Given the relationship between obesogenic risk factors (physical activity, sedentary behavior and diet) and depressive symptoms among adolescents [46], this important outcome will be examined. The Short Mood and Feelings Questionnaire (SMFQ) [47] has previously demonstrated high internal consistency among Australian children aged $10-14$ years $(\alpha>0.85)$ [48], with the additional benefit of having international application and validation among children and adolescents [47]. The SMFQ was selected to examine depressive symptoms as clinical diagnosis of depression through clinical psychiatric interviews is impractical for population based-studies [47]. Due to the nature of the questionnaire items, it was felt that the questionnaire be administered to secondary school students only (Grade 8 and Grade 10), despite being psychometrically tested among Australian children as young as 10 years of age [48]. The responses from the questionnaire will be collated into a SMFQ score, which will be used as a measure of depressive symptomology. 


\section{Demographic characteristics}

Demographic characteristics of participants will be captured through the self-report questionnaire and include: date of birth, gender, residential postcode, language spoken at home, country of birth and ancestry. These characteristics will be used primarily as covariates for the primary and secondary outcome measures.

\section{School environments}

Within each participating school, approximately 1-3 members of staff will be invited to complete a school environment audit (Primary Schools: Be Active Eat Well Environment questionnaire Secondary schools: It's Your Move Environment Questionnaire). This survey, examines the schools' policies and environments in relation to physical activity and healthy eating (e.g., number and type of physical activity and healthy eating policies; types of unhealthy food available in school canteens and distance of nearest takeaway shop, frequency and duration of physical education and sport education). This survey takes approximately 15 min to complete and will be conducted during the school day (typically at recess or lunch) [49]. These questionnaires were developed for two previous community-based interventions and were examined for face validity by the study's executive but these instruments have not been subject to formal psychometric testing due to the nature of the question items. School policy, physical, economic and socio-cultural environments will be examined for change over time and their relationship with obesity and associated risk factors.

\section{Data analysis}

Cross-sectional (within year) and longitudinal (across region/LGA) multilevel analyses will be conducted to consider different exposure variables (condition) and the effects of clustering (within school, between LGA) and other potential confounders (age, gender, socioeconomic position). A multilevel growth model [50] will be used to examine how BMI z-score, and other dependent variables (physical activity, sedentary behavior, diet quality, wellbeing), change over the three waves of data collection. A growth model will be used because it accommodates; 1 ) modelling of change over time; and, 2) simultaneous modelling of change occurring within an LGA over time, and between LGAs over time.

\section{Research plan aim 2: to measure the effects of change to community-level system factors on rates of childhood obesity among Victorian children}

Since HTV aims to create change at the community (LGA level) as well as the school (setting level), the proposed research plan under Aim 2 is designed to enhance understanding of how HTV has created community-level system change. It is hypothesized that:
1. HTV changes elements of local community-level systems that influence childhood obesity

2. Differential changes in local community-level systems have differential effects on the LGA policy environment, school environments, child behavior and subsequent weight status

The Foresight obesity systems map [13] represents a watershed moment for systems thinking and obesity prevention as it provides the first visual representation of the complex causes of obesity. The resulting map begins with obesity at an individual level and builds to a peripheral set of 108 variables, clustered in seven domains (physiology, individual physical activity, physical activity environment, individual psychology, social psychology, food consumption and food production) that directly or indirectly influence obesity [13]. Five of these domains (individual physical activity, physical activity environment, individual psychology, social psychology and food consumption) will be incorporated into the analysis. The domains of physiology and food production have not been included at this time as the data are not readily available or are not collected at a population level. For example, physiology includes 'level of satiety' and level of thermogenesis', both of which are not easily collected en masse. Similarly the food production domain contains variables which are difficult to measure such as 'Palatability of food offerings' and 'Pressure for growth and profitability'.

\section{Study design and sampling}

In order to test the stated hypothesises, data routinely collected by the Victorian Department of Health and Human Services plus other freely available data will be used to map accepted relationships between childhood obesity and its determinants as defined by the Foresight obesity systems map at the LGA level [13]. A detailed description of the study design, sampling strategy, protocols and procedures for each of these data sources are outlined in Table 2. Table 3 provides details of the available data items that will be used in the analysis of the systems influencing obesity. The data sources contain a mixture of child and adult data. While the primary interest of this study is childhood obesity, it is obesity at an LGA level not at an individual level. Data collected only from adults such as 'Health Literacy for Healthy Eating and Physical Activity', 'Affective attitudes (facilitators \& barriers, decisional balance) for Healthy Eating and Physical Activity', and 'Self-efficacy for Healthy Eating and Physical Activity' will be used to populate parameters at the LGA level as these are seen as systems indicators. Similarly adult anthropometric data will be included in the models in order to control for the influence of adult BMI on child BMI. It would be expected that there would 
Table 2 Detailed description of datasets to be incorporated in Aim 2

\begin{tabular}{|c|c|c|c|c|}
\hline Survey & $\begin{array}{l}\text { Description (Study design, } \\
\text { sampling and study protocol) }\end{array}$ & $\begin{array}{l}\text { Participants, recruitment } \\
\text { measures and procedures }\end{array}$ & Outcome(s) of interest & Instrument/measure \\
\hline \multirow{3}{*}{$\begin{array}{l}\text { Victorian Population } \\
\text { Health Survey (VPHS) [58] }\end{array}$} & \multirow[b]{3}{*}{$\begin{array}{l}\text { Established in 1998, the VPHS } \\
\text { is a Victorian representative } \\
\text { surveillance survey that } \\
\text { collects detailed information } \\
\text { on the health, lifestyle and } \\
\text { wellbeing status of Victorian } \\
\text { adults. Random digit dialling } \\
\text { of registered telephone } \\
\text { numbers was used in each } \\
\text { study year (annually from } \\
\text { 2001) with participants } \\
\text { completing a computer } \\
\text { assisted telephone interview } \\
\text { (CATI). In } 2008 \text { and } 2011 / 12 \text {, } \\
\text { sampling occurred in all of } \\
\text { the } 79 \text { LGAs within Victoria and } \\
\text { represented baseline measures for } \\
\text { HTV. A target sample of } 426 \text { interviews } \\
\text { per LGA was achieved. Triennial } \\
\text { LGA-level data collection among } \\
\text { over } 33,000 \text { is envisaged for the } \\
\text { duration of the HTV (2014 and 2017). }\end{array}$} & \multirow{3}{*}{$\begin{array}{l}\text { - } 33,673 \text { adults ( } \geq 18 \text { years) } \\
\text { in private dwellings recorded } \\
\text { complete interviews between } \\
\text { Sept } 24 \text { and Dec } 162008 \text { in } \\
\text { HTC intervention and } \\
\text { comparison communities } \\
\text { - All residential households with } \\
\text { land-line telephone connections } \\
\text { were considered eligible for } \\
\text { the study } \\
\text { - Interviewers made up to six calls } \\
\text { on different days of the week and } \\
\text { times to establish contact with } \\
\text { the household, which was } \\
\text { controlled by a customised call } \\
\text { algorithm } \\
\text { - The average interview length } \\
\text { was approximately } 22 \text { min. } \\
\text { - The response rate was } 64.9 \% \text {. }\end{array}$} & \multirow{3}{*}{$\begin{array}{l}\text { - Change in BMI score } \\
\text { - Change in overweight } \\
\text { and obesity prevalence } \\
\text { - Change in fruit and } \\
\text { vegetable intake } \\
\text { - Change in the proportion } \\
\text { meeting the Australian } \\
\text { physical activity guidelines } \\
\text { for adults [59] }\end{array}$} & Self-rated health status \\
\hline & & & & $\begin{array}{l}\text { CATI (smoking, fruit and vegetable } \\
\text { intake, alcohol consumption, levels of PA) }\end{array}$ \\
\hline & & & & Self-reported height and weight \\
\hline \multirow[t]{2}{*}{$\begin{array}{l}\text { Preventive Health Survey } \\
\text { (PHS) }\end{array}$} & \multirow{2}{*}{$\begin{array}{l}\text { The Preventive Health Survey was } \\
\text { undertaken in } 2011 / 12 \text { and is again } \\
\text { scheduled for completion in } \\
2016 / 2017 \text {. The PHS furthers the } \\
\text { information derived from the VPHS } \\
\text { as it is able to make comparison } \\
\text { estimates for each intervention HTV } \\
\text { area compared to its' matched-control } \\
\text { area. This is in contrast to the VPHS, } \\
\text { which can only make estimates for } \\
\text { intervention and comparison HTV } \\
\text { areas combined. }\end{array}$} & \multirow{2}{*}{$\begin{array}{l}\cdot \geq 9,500 \text { adults ( } \geq 18 \text { years) and } \\
\geq 1800 \text { children ( } 5-18 \text { years) } \\
\text { randomly sampled from HTV } \\
\text { intervention and comparison } \\
\text { communities }\end{array}$} & \multirow{2}{*}{$\begin{array}{l}\text { - Change in BMI } \\
\text { - Change in overweight } \\
\text { and obesity prevalence } \\
\text { - Change in the proportion } \\
\text { of participants meeting } \\
\text { Australia's physical activity } \\
\text { and sedentary behavior } \\
\text { guidelines for children } \\
\text { (5-12 years) [33] and young } \\
\text { people (13-18 years) [34] } \\
\text { - Change in the proportion } \\
\text { of participants eating the } \\
\text { required amount of fruit } \\
\text { and vegetables [39] }\end{array}$} & $\begin{array}{l}\text { Self-rated health status CATI (PA, SB } \\
\text { environmental amenity, perceived barriers } \\
\text { and facilitators to healthy eating and activity) }\end{array}$ \\
\hline & & & & Self-reported height and weight \\
\hline School Activity Audits & $\begin{array}{l}\text { The Healthy Together Achievement } \\
\text { Program is currently being offered } \\
\text { to all Victorian Primary and Secondary } \\
\text { schools. The program began in 2011, } \\
\text { and was developed by the Department } \\
\text { of Education and Training and } \\
\text { Department of Health \& Human Services } \\
\text { (Victoria). The Achievement Program is } \\
\text { designed to support schools to become } \\
\text { health promoting schools and aide in the } \\
\text { attainment of state-wide benchmarks for } \\
\text { health promotion. Through participation }\end{array}$ & $\begin{array}{l}\text { - Primary and Secondary Schools } \\
\text { involved in the Healthy Together } \\
\text { Achievement Program } \\
\text { - The schools' Achievement } \\
\text { Program } \\
\text { Coordinator completes the } \\
\text { audits via the online registration } \\
\text { system. }\end{array}$ & $\begin{array}{l}\text { - Uptake and dispersion of } \\
\text { the Achievement Program } \\
\text { across Victoria } \\
\text { - Change in progression } \\
\text { through the various stages } \\
\text { of the Achievement } \\
\text { Program and achievement } \\
\text { of benchmarks among HTV } \\
\text { and comparison communities } \\
\text { over time. }\end{array}$ & Online School Activity audit \\
\hline
\end{tabular}


Table 2 Detailed description of datasets to be incorporated in Aim 2 (Continued)

in the Achievement program, schools provide information on the schools' engagement in prevention efforts.

LGA Policy Metrics

The Victorian Department of Health

- Content analysis of municipal

documents from 79 LGAs in

\& Human Services has conducted a content analysis of Municipal Public

Health and Wellbeing Plans and

Victoria

Council Plans in relation to healthy

eating and physical activity, as well

as other health and wellbeing priorities,

of the 79 LGAs in Victoria. Local

council plans between 2009 and 2013

have been audited in line with the 4 year

municipal planning cycles.
- Evaluation of changes in the number and type of health and wellbeing policies within HTV

intervention and comparison

$$
\text { communities }
$$


Table 3 Details of the Foresight domains [59] and variables and the items that will be used to measure them

\begin{tabular}{|c|c|c|c|c|}
\hline $\begin{array}{l}\text { Foresight } \\
\text { domain }\end{array}$ & Foresight variable & Foresight description & Data collection tool & Item \\
\hline \multirow[t]{22}{*}{$\begin{array}{l}\text { Physical } \\
\text { activity } \\
\text { environment }\end{array}$} & $\begin{array}{l}\text { Accessibility to } \\
\text { opportunities for } \\
\text { physical exercise }\end{array}$ & $\begin{array}{l}\text { Physical accessibility (distance, safety) } \\
\text { of opportunities for physical exercise }\end{array}$ & PHS & $\begin{array}{l}\text { Perceived environmental } \\
\text { amenity }\end{array}$ \\
\hline & \multirow{3}{*}{$\begin{array}{l}\text { Ambient } \\
\text { temperature }\end{array}$} & \multirow{3}{*}{$\begin{array}{l}\text { Average environmental temperature } \\
\text { indoors }\end{array}$} & Not available from surveys. & \multirow[t]{5}{*}{ Ambient temperature } \\
\hline & & & Bureau Of Meteorology (BOM) & \\
\hline & & & $\begin{array}{l}\text { http://www.bom.gov.au/products/ } \\
\text { IDV65079.shtml }\end{array}$ & \\
\hline & \multirow{2}{*}{$\begin{array}{l}\text { Cost of physical } \\
\text { exercise }\end{array}$} & \multirow[t]{2}{*}{ Financial cost of physical recreation } & Not available from surveys & \\
\hline & & & Data available from individual LGAs & \\
\hline & \multirow{3}{*}{$\begin{array}{l}\text { Dominance of } \\
\text { motorised } \\
\text { transport }\end{array}$} & \multirow{3}{*}{$\begin{array}{l}\text { Degree to which motorised transport } \\
\text { dominates other ways of transport }\end{array}$} & PHS & \multirow{2}{*}{$\begin{array}{l}\text { Perceived environmental } \\
\text { amenity }\end{array}$} \\
\hline & & & \multirow[t]{2}{*}{ Data available from individual LGAs } & \\
\hline & & & & Availability of public transport \\
\hline & $\begin{array}{l}\text { Dominance of } \\
\text { sedentary } \\
\text { employment }\end{array}$ & $\begin{array}{l}\text { Degree to which average citizens } \\
\text { influence one another's choices }\end{array}$ & Data available from individual LGAs & Employment statistics \\
\hline & \multirow{2}{*}{$\begin{array}{l}\text { Opportunity for } \\
\text { team-based } \\
\text { activity }\end{array}$} & \multirow[t]{2}{*}{ N/A } & Not available from surveys & \multirow{2}{*}{$\begin{array}{l}\text { Register of the number of } \\
\text { sporting clubs in each LGA }\end{array}$} \\
\hline & & & Data available from individual LGAs & \\
\hline & $\begin{array}{l}\text { Opportunity for } \\
\text { unmotorised } \\
\text { transport }\end{array}$ & $\begin{array}{l}\text { Availability of facilities/infrastructure } \\
\text { for unmotorised transport }\end{array}$ & PHS & $\begin{array}{l}\text { Perceived environmental } \\
\text { amenity }\end{array}$ \\
\hline & $\begin{array}{l}\text { Perceived danger } \\
\text { in environment }\end{array}$ & N/A & $\begin{array}{l}\text { Available from the Community } \\
\text { Indicators Victoria website by LGA }\end{array}$ & Perceptions of safety \\
\hline & $\begin{array}{l}\text { Reliance of labor- } \\
\text { saving devices }\end{array}$ & $\begin{array}{l}\text { Reliance on labor-saving devices for } \\
\text { daily chores }\end{array}$ & Not available from surveys & \\
\hline & $\begin{array}{l}\text { Safety of } \\
\text { unmotorised } \\
\text { transport }\end{array}$ & $\begin{array}{l}\text { Level of risk for harm by engaging in } \\
\text { non-motorised transport }\end{array}$ & PHS & $\begin{array}{l}\text { Perceived environmental } \\
\text { amenity }\end{array}$ \\
\hline & \multirow{2}{*}{$\begin{array}{l}\text { Social } \\
\text { depreciation of } \\
\text { labor }\end{array}$} & \multirow{2}{*}{$\begin{array}{l}\text { Degree to which manual labor is } \\
\text { negatively valued in a given } \\
\text { socio-cultural group }\end{array}$} & Not available from surveys & \multirow[t]{2}{*}{ Employment demographics } \\
\hline & & & $\begin{array}{l}\text { Can be inferred from the local } \\
\text { demographics available on the Local } \\
\text { Government websites }\end{array}$ & \\
\hline & $\begin{array}{l}\text { Sociocultural } \\
\text { valuation of } \\
\text { physical activity }\end{array}$ & $\begin{array}{l}\text { Degree to which physical activity is } \\
\text { positively valued in a given socio- } \\
\text { cultural group }\end{array}$ & PHS & $\begin{array}{l}\text { Social environment (social } \\
\text { norms) for HEPA }\end{array}$ \\
\hline & \multirow{3}{*}{$\begin{array}{l}\text { Walkability of } \\
\text { living } \\
\text { environment }\end{array}$} & & PHS & \multirow{3}{*}{$\begin{array}{l}\text { Perceived environmental } \\
\text { amenity } \\
\text { School walkability }\end{array}$} \\
\hline & & & Available from the Community & \\
\hline & & & Indicators Victoria website by LGA & \\
\hline \multirow[t]{6}{*}{$\begin{array}{l}\text { Individual } \\
\text { physical } \\
\text { activity }\end{array}$} & $\begin{array}{l}\text { Degree of innate } \\
\text { activity in } \\
\text { childhood }\end{array}$ & $\begin{array}{l}\text { Degree to which physical activity is } \\
\text { part of typical childhood behavior }\end{array}$ & PHS and WHOCC surveys & Level of physical activity \\
\hline & \multirow{3}{*}{$\begin{array}{l}\text { Degree of } \\
\text { physical } \\
\text { education }\end{array}$} & \multirow{3}{*}{$\begin{array}{l}\text { Degree to which people have learned } \\
\text { to use their body (for labor, leisure } \\
\text { and transport) }\end{array}$} & VPHS & \multirow{2}{*}{$\begin{array}{l}\text { Frequency and amount of } \\
\text { vigorous physical activity in past } \\
\text { week }\end{array}$} \\
\hline & & & PHS & \\
\hline & & & & Physical Activity and sedentary \\
\hline & \multirow[t]{2}{*}{ Functional fitness } & \multirow{2}{*}{$\begin{array}{l}\text { Level of physical fitness to perform } \\
\text { daily tasks }\end{array}$} & VPHS & Self-reported health status \\
\hline & & & WHOCC & $\begin{array}{l}\text { Paediatric Quality of Life } \\
\text { Inventory (PedsQL) [40] }\end{array}$ \\
\hline
\end{tabular}

Learned activity patterns in early childhood
Degree of activity experienced by the foetus, newborn and child in
Not available from surveys 
Table 3 Details of the Foresight domains [59] and variables and the items that will be used to measure them (Continued)

\begin{tabular}{|c|c|c|c|c|}
\hline & & $\begin{array}{l}\text { early life through parental physical } \\
\text { activity }\end{array}$ & & \\
\hline & $\begin{array}{l}\text { Level of domestic } \\
\text { activity }\end{array}$ & $\begin{array}{l}\text { Level of physical activity exhibited in } \\
\text { the domestic arena }\end{array}$ & VPHS & Physical activity at work \\
\hline & $\begin{array}{l}\text { Level of } \\
\text { occupational } \\
\text { activity }\end{array}$ & $\begin{array}{l}\text { Level of physical activity associated } \\
\text { to professional duties }\end{array}$ & VPHS & Physical activity at work \\
\hline & \multirow{3}{*}{$\begin{array}{l}\text { Level of } \\
\text { recreational } \\
\text { activity }\end{array}$} & \multirow{3}{*}{$\begin{array}{l}\text { Degree to which people engage in } \\
\text { physical activity for recreation }\end{array}$} & VPHS & \multirow{2}{*}{$\begin{array}{l}\text { Frequency and amount of } \\
\text { vigorous physical activity in past } \\
\text { week }\end{array}$} \\
\hline & & & PHS & \\
\hline & & & & \multirow[t]{3}{*}{ Physical Activity and sedentary } \\
\hline & \multirow{2}{*}{$\begin{array}{l}\text { Level of transport } \\
\text { activity }\end{array}$} & \multirow{2}{*}{$\begin{array}{l}\text { Level of physical activity associated } \\
\text { to transport }\end{array}$} & Not available from surveys & \\
\hline & & & $\begin{array}{l}\text { Available from the Community } \\
\text { Indicators Victoria website by LGA for } \\
\text { Melbourne metropolitan area only }\end{array}$ & \\
\hline & $\begin{array}{l}\text { Non-volitional } \\
\text { activity (NEAT) }\end{array}$ & $\begin{array}{l}\text { extent to which people engage in } \\
\text { non-volitional activity (twitching etc.) }\end{array}$ & Not available from surveys & \\
\hline & \multirow{2}{*}{$\begin{array}{l}\text { Parental } \\
\text { modelling of } \\
\text { activity }\end{array}$} & \multirow{2}{*}{$\begin{array}{l}\text { Degree to which parents act as a } \\
\text { role model in physical activity related } \\
\text { behavioral patterns }\end{array}$} & \multirow[t]{2}{*}{ PHS } & Parent physical activity \\
\hline & & & & Child physical activity \\
\hline & \multirow[t]{3}{*}{ Physical activity } & \multirow{3}{*}{$\begin{array}{l}\text { Level of physical activity people } \\
\text { engage in }\end{array}$} & VPHS & \multirow{2}{*}{$\begin{array}{l}\text { Frequency and amount of } \\
\text { vigorous physical activity in past } \\
\text { week }\end{array}$} \\
\hline & & & PHS & \\
\hline & & & & Physical Activity and sedentary \\
\hline \multirow{16}{*}{$\begin{array}{l}\text { Social } \\
\text { psychology }\end{array}$} & \multirow[t]{4}{*}{ Acculturation } & \multirow{4}{*}{$\begin{array}{l}\text { Degree to which a (dominant) } \\
\text { culture is assimilated }\end{array}$} & \multirow[t]{4}{*}{ VPHS } & Country of birth \\
\hline & & & & Main language spoken at home \\
\hline & & & & Country of birth of mother \\
\hline & & & & Country of birth of father \\
\hline & $\begin{array}{l}\text { Availability of } \\
\text { passive } \\
\text { entertainment } \\
\text { options }\end{array}$ & $\begin{array}{l}\text { Availability of recreational options } \\
\text { that involve only limited physical } \\
\text { exercise (tv, computer games) }\end{array}$ & PHS & \multirow[t]{3}{*}{ Sedentary behavior items } \\
\hline & $\begin{array}{l}\text { Children's control } \\
\text { of diet }\end{array}$ & $\begin{array}{l}\text { Degree to which children exert } \\
\text { influence on dietary choices in a } \\
\text { family }\end{array}$ & Not available from surveys & \\
\hline & $\begin{array}{l}\text { Conceptualisation } \\
\text { of obesity as a } \\
\text { disease }\end{array}$ & $\begin{array}{l}\text { Degree to which people consider } \\
\text { obesity to be an abnormal deviation } \\
\text { from the healthy norm }\end{array}$ & Not available from surveys & \\
\hline & Education & N/A & VPHS \& PHS & Demographics \\
\hline & \multirow{2}{*}{$\begin{array}{l}\text { Exposure to food } \\
\text { advertising }\end{array}$} & \multirow[t]{2}{*}{ N/A } & Not available from surveys & \multirow{3}{*}{$\begin{array}{l}\text { Level of exposure to food } \\
\text { advertising }\end{array}$} \\
\hline & & & Available from the literature & \\
\hline & $\begin{array}{l}\text { Importance of } \\
\text { ideal body-size } \\
\text { image }\end{array}$ & $\begin{array}{l}\text { Degree to which there is a dominant } \\
\text { image of an ideal body size in a society }\end{array}$ & Not available from surveys & \\
\hline & \multirow[t]{2}{*}{ Media availability } & \multirow[t]{2}{*}{ Availability of media across formats } & Not available from surveys & \multirow{2}{*}{$\begin{array}{l}\text { Data on availability of all types of } \\
\text { media }\end{array}$} \\
\hline & & & $\begin{array}{l}\text { The Victorian Government digital } \\
\text { innovation review Part B: The digital } \\
\text { readiness of Victorian citizens }\end{array}$ & \\
\hline & \multirow{2}{*}{$\begin{array}{l}\text { Media } \\
\text { consumption }\end{array}$} & \multirow{2}{*}{$\begin{array}{l}\text { Degree to which people make use } \\
\text { of the media offerings }\end{array}$} & Not available from surveys & \multirow{3}{*}{$\begin{array}{l}\text { Data on use of all types of } \\
\text { media }\end{array}$} \\
\hline & & & $\begin{array}{l}\text { The Victorian Government digital } \\
\text { innovation review Part B: The digital } \\
\text { readiness of Victorian citizens }\end{array}$ & \\
\hline & \multicolumn{2}{|l|}{ Parental control } & Not available from surveys & \\
\hline
\end{tabular}


Table 3 Details of the Foresight domains [59] and variables and the items that will be used to measure them (Continued)

\begin{tabular}{|c|c|c|c|c|}
\hline & & $\begin{array}{l}\text { Level of control exerted by parents } \\
\text { on children's choices }\end{array}$ & & \\
\hline & Peer pressure & $\begin{array}{l}\text { Degree to which average citizens } \\
\text { influence one another's choices }\end{array}$ & PHS & $\begin{array}{l}\text { Social environment (social } \\
\text { norms) for Healthy Eating and } \\
\text { Physical Activity }\end{array}$ \\
\hline & $\begin{array}{l}\text { Perceived lack of } \\
\text { time }\end{array}$ & $\begin{array}{l}\text { By all citizens, particularly those } \\
\text { engaged in economic activity }\end{array}$ & PHS & $\begin{array}{l}\text { Instrumental beliefs (facilitators \& } \\
\text { barriers, decisional balance) for } \\
\text { Healthy Eating and Physical } \\
\text { Activity }\end{array}$ \\
\hline & $\begin{array}{l}\text { Smoking } \\
\text { cessation }\end{array}$ & Number of people quitting smoking & VPHS & $\begin{array}{l}\text { Number of people smoking from } \\
\text { one survey to the next }\end{array}$ \\
\hline & $\begin{array}{l}\text { Social } \\
\text { acceptability of } \\
\text { fatness }\end{array}$ & N/A & VPHS \& PHS & $\begin{array}{l}\text { Height and weight; BMI } \\
\text { heterogeneity between LGAs }\end{array}$ \\
\hline & $\begin{array}{l}\text { Sociocultural } \\
\text { valuation of food }\end{array}$ & $\begin{array}{l}\text { Degree to which food is positively } \\
\text { valued within a given socio-cultural } \\
\text { group }\end{array}$ & PHS & Instrumental \\
\hline & TV watching & Time spent watching tv & PHS & Sedentary behavior \\
\hline $\begin{array}{l}\text { Individual } \\
\text { psychology }\end{array}$ & $\begin{array}{l}\text { Demand for } \\
\text { indulgence/ } \\
\text { compensation }\end{array}$ & $\begin{array}{l}\text { Strength of demand for psychological } \\
\text { release after stress or effort }\end{array}$ & Not available from surveys & \\
\hline & $\begin{array}{l}\text { Desire to resolve } \\
\text { tension }\end{array}$ & $\begin{array}{l}\text { Desire to resolve psychological } \\
\text { conflict between what people } \\
\text { desire and what they need to } \\
\text { stay healthy }\end{array}$ & PHS & $\begin{array}{l}\text { Affective attitudes (facilitators \& } \\
\text { barriers, decisional balance) for } \\
\text { Healthy Eating and Physical } \\
\text { Activity }\end{array}$ \\
\hline & & & & Combined with \\
\hline & & & & $\begin{array}{l}\text { Behavioral intentions (desire to } \\
\text { change behavior) for HEPA }\end{array}$ \\
\hline & & & & $\begin{array}{l}\text { And Daily vegetable } \\
\text { consumption }\end{array}$ \\
\hline & & & & Daily fruit consumption \\
\hline & & & & $\begin{array}{l}\text { Physical Activity Sedentary } \\
\text { behavior }\end{array}$ \\
\hline & & & & $\begin{array}{l}\text { beliefs (facilitators \& barriers, } \\
\text { decisional balance) for Healthy } \\
\text { Eating and Physical Activity }\end{array}$ \\
\hline & Food literacy & $\begin{array}{l}\text { Degree to which people are able } \\
\text { to assess nutritional quality and } \\
\text { provenance }\end{array}$ & PHS & $\begin{array}{l}\text { Health Literacy for Healthy } \\
\text { Eating and Physical Activity }\end{array}$ \\
\hline & Individualism & Weakness of social fabric & PHS & Social environment (social \\
\hline & & & $\begin{array}{l}\text { vailable from the Community } \\
\text { Indicators Victoria website by LGA }\end{array}$ & $\begin{array}{l}\text { norms) for Healthy Eating and } \\
\text { Physical Activity }\end{array}$ \\
\hline & & & & Level of social support \\
\hline & $\begin{array}{l}\text { Perceived } \\
\text { inconsistency of } \\
\text { science-based } \\
\text { messages }\end{array}$ & $\begin{array}{l}\text { Degree to which there is } \\
\text { incompatibility between scientific } \\
\text { assessments on } \\
\text { food related issues which (are } \\
\text { perceived) to be similar }\end{array}$ & PHS & $\begin{array}{l}\text { Health Literacy for Healthy } \\
\text { Eating and Physical Activity }\end{array}$ \\
\hline & $\begin{array}{l}\text { Psychological } \\
\text { ambivalence }\end{array}$ & $\begin{array}{l}\text { Degree to which people experience } \\
\text { a psychological conflict between } \\
\text { what people desire (e.g., fatty, sweet } \\
\text { foods) and the need to stay healthy }\end{array}$ & PHS & $\begin{array}{l}\text { Affective attitudes (facilitators \& } \\
\text { barriers, decisional balance) for } \\
\text { Healthy Eating and Physical } \\
\text { Activity }\end{array}$ \\
\hline & Self esteem & $\begin{array}{l}\text { Sense of purpose and self-confidence } \\
\text { of individuals }\end{array}$ & PHS & $\begin{array}{l}\text { Self-efficacy for Healthy Eating } \\
\text { and Physical Activity }\end{array}$ \\
\hline & Stress & Perceived level of stress by individuals & VPHS & $\begin{array}{l}\text { Psychological distress (Kessler } 10 \\
\text { Psychological Distress Scale) }\end{array}$ \\
\hline
\end{tabular}


Table 3 Details of the Foresight domains [59] and variables and the items that will be used to measure them (Continued)

\begin{tabular}{|c|c|c|c|c|}
\hline & Use of medicines & $\mathrm{N} / \mathrm{A}$ & VPHS & Diabetes status \\
\hline & & & & Type of diabetes \\
\hline & & & & $\begin{array}{l}\text { Age first diagnosed with } \\
\text { diabetes }\end{array}$ \\
\hline & & & & $\begin{array}{l}\text { Type of healthcare received in } \\
\text { past year }\end{array}$ \\
\hline \multirow[t]{30}{*}{$\begin{array}{l}\text { Food } \\
\text { consumption }\end{array}$} & \multirow[t]{5}{*}{$\begin{array}{l}\text { Alcohol } \\
\text { consumption }\end{array}$} & \multirow[t]{5}{*}{ N/A } & \multirow[t]{5}{*}{ VPHS } & $\begin{array}{l}\text { Whether had an alcoholic drink } \\
\text { of any kind in previous }\end{array}$ \\
\hline & & & & 12 months \\
\hline & & & & $\begin{array}{l}\text { Frequency of having an alcoholic } \\
\text { drink of any kind }\end{array}$ \\
\hline & & & & $\begin{array}{l}\text { Amount of standard drinks } \\
\text { consumed when drinking }\end{array}$ \\
\hline & & & & $\begin{array}{l}\text { Level of frequency of high-risk } \\
\text { drinking }\end{array}$ \\
\hline & $\begin{array}{l}\text { Convenience of } \\
\text { food offerings }\end{array}$ & $\begin{array}{l}\text { The degree to which food offerings } \\
\text { cater to the desire for convenience }\end{array}$ & PHS & Food accessibility \\
\hline & $\begin{array}{l}\text { Demand for } \\
\text { convenience }\end{array}$ & $\begin{array}{l}\text { Consumer demand for convenient } \\
\text { (time/effort saving) food offerings }\end{array}$ & PHS & $\begin{array}{l}\text { Instrumental beliefs (facilitators \& } \\
\text { barriers, decisional balance) for } \\
\text { Healthy Eating and Physical } \\
\text { Activity }\end{array}$ \\
\hline & \multirow[t]{3}{*}{ De-skilling } & \multirow{3}{*}{$\begin{array}{l}\text { The degree to which individuals are } \\
\text { not able anymore to engage } \\
\text { independently in routine tasks for } \\
\text { daily living (such as cooking) }\end{array}$} & \multirow[t]{3}{*}{ VPHS } & Self-reported health status \\
\hline & & & & Combined with \\
\hline & & & & $\begin{array}{l}\text { Number and type of chronic } \\
\text { diseases }\end{array}$ \\
\hline & \multirow{8}{*}{$\begin{array}{l}\text { Energy-density of } \\
\text { food offerings }\end{array}$} & \multirow{8}{*}{$\begin{array}{l}\text { Number of calories per unit food } \\
\text { weight }\end{array}$} & VPHS & \multirow{2}{*}{$\begin{array}{l}\text { Calculated from: Daily vegetable } \\
\text { consumption }\end{array}$} \\
\hline & & & PHS & \\
\hline & & & & Daily fruit consumption \\
\hline & & & & Milk consumption \\
\hline & & & & Water consumption \\
\hline & & & & $\begin{array}{l}\text { Consumption of sugar- } \\
\text { sweetened soft drinks }\end{array}$ \\
\hline & & & & Daily vegetable consumption \\
\hline & & & & Daily fruit consumption \\
\hline & \multirow{7}{*}{$\begin{array}{l}\text { Fibre content of } \\
\text { Food \& Drink }\end{array}$} & \multirow[t]{7}{*}{ N/A } & VPHS & Daily vegetable consumption \\
\hline & & & \multirow[t]{6}{*}{ PHS } & Daily fruit consumption \\
\hline & & & & Milk consumption \\
\hline & & & & Water consumption \\
\hline & & & & $\begin{array}{l}\text { Consumption of sugar- } \\
\text { sweetened soft drinks }\end{array}$ \\
\hline & & & & Daily vegetable consumption \\
\hline & & & & Daily fruit consumption \\
\hline & \multirow[t]{2}{*}{ Food abundance } & \multirow{2}{*}{$\begin{array}{l}\text { The aggregate amount of food } \\
\text { (volume) that is at any moment } \\
\text { in time available in UK (AU) society }\end{array}$} & Not available from surveys & \multirow{5}{*}{$\begin{array}{l}\text { The amount of food available } \\
\text { per person in Australia }\end{array}$} \\
\hline & & & $\begin{array}{l}\text { Australian Institute of Health and } \\
\text { Welfare 2012. Australia's food \& } \\
\text { nutrition 2012. Cat. no. PHE } 163 . \\
\text { Canberra: AlHW. }\end{array}$ & \\
\hline & \multirow[t]{2}{*}{ Food exposure } & \multirow{3}{*}{$\begin{array}{l}\text { The number of food cues individuals } \\
\text { are confronted with on a daily basis }\end{array}$} & Not available from surveys & \\
\hline & & & Available from the literature & \\
\hline & Food variety & & Not available from surveys & \\
\hline
\end{tabular}


Table 3 Details of the Foresight domains [59] and variables and the items that will be used to measure them (Continued)

\begin{tabular}{|c|c|c|c|}
\hline & $\begin{array}{l}\text { The number of different food } \\
\text { products (natural and processed) } \\
\text { available at } \\
\text { any moment in time }\end{array}$ & $\begin{array}{l}\text { Australian Institute of Health and } \\
\text { Welfare 2012. Australia's food \& } \\
\text { nutrition 2012. Cat. no. PHE } 163 \text {. } \\
\text { Canberra: AlHW. }\end{array}$ & $\begin{array}{l}\text { Categories of the amount of } \\
\text { food available per person in } \\
\text { Australia }\end{array}$ \\
\hline $\begin{array}{l}\text { Force of dietary } \\
\text { habits }\end{array}$ & $\begin{array}{l}\text { The degree to which behavioral } \\
\text { patterns related to food intake are } \\
\text { dictated by routine and habit }\end{array}$ & PHS & $\begin{array}{l}\text { Habit strength for Healthy Eating } \\
\text { and Physical Activity }\end{array}$ \\
\hline \multirow{7}{*}{$\begin{array}{l}\text { Nutritional quality } \\
\text { of Food \& Drink }\end{array}$} & \multirow[t]{7}{*}{ N/A } & VPHS & Daily vegetable consumption \\
\hline & & \multirow[t]{6}{*}{ PHS } & Daily fruit consumption \\
\hline & & & Milk consumption \\
\hline & & & Water consumption \\
\hline & & & $\begin{array}{l}\text { Consumption of sugar- } \\
\text { sweetened soft drinks }\end{array}$ \\
\hline & & & Daily vegetable consumption \\
\hline & & & Daily fruit consumption \\
\hline $\begin{array}{l}\text { Palatability of } \\
\text { food offerings }\end{array}$ & \multirow[t]{2}{*}{ N/A } & Not available from surveys & \\
\hline Portion size & & Not available from surveys & \\
\hline Rate of eating & $\begin{array}{l}\text { Time-span devoted to consuming } \\
\text { a meal }\end{array}$ & Not available from surveys & \\
\hline $\begin{array}{l}\text { Tendency to } \\
\text { graze }\end{array}$ & $\begin{array}{l}\text { Tendency to eat outside fixed } \\
\text { meal times }\end{array}$ & Not available from surveys & \\
\hline
\end{tabular}

be a medium to strong correlation even at the LGA level between these variables. How these systems indicators plus individual level behaviors impact childhood obesity will then be tested.

\section{Data analysis}

The Foresight map will be used as a basis to model relationships within and between the domains so as to demonstrate which elements of the system are changing, the strength of these changes, the elements that are resisting change and the implications of these relationships for childhood obesity.

The outlined datasets contain $>75 \%$ of the 65 variables within five domains of the Foresight map (individual physical activity, physical activity environment, individual psychology, social psychology and food consumption) and various techniques will be used to test the hypotheses. For hypothesis 1: HTV changes elements of local communitylevel systems that influence childhood obesity, a series of mixed effects linear regression analyses will be used. Prior to the analyses, a confirmatory factor analysis will be utilised to reduce the data within each of the Foresight domains so a factor score is obtained. Each of the factors will then be used as the dependent variable with the independent variable being study condition (HTV or nonHTV) interacting with time adjusted for hypothesised covariates. The resulting predictions will be plotted and compared to the changes in childhood obesity from Aim 1. Positive changes in each of the domains in HTC compared to non-HTC combined with positive changes in childhood obesity over the same time period would provide support for Hypothesis 1.

For hypothesis 2: Differential changes in local community-level systems have differential effects on the LGA policy environment, school environments, child behavior and subsequent weight status, a series of multi-level (individual and LGA) structural equation models will be used. The main area of interest will be the LGA level as it is the heterogeneity at this level that is important in testing hypothesis two. The first model will test the influence of each of the domains on one another plus policies within LGAs. The second will substitute school environments as the dependent variable, the third child behavior and the fourth child weight status. Child weight status will be calculated using the self-reported data from the PHS. These data will be used as they have corresponding adult data that can be used in calculating the systems-level exposures. Sensitivity analyses will be undertaken in order to calculate the differences in child weight status between the measured and self-report groups. Depending on findings, weightings may be used to correct the difference.

Using this approach, the impact of changes within each of the five domains can be quantified and the relative contribution of each domain to LGA policy environment (continuous score of number of obesity related policies calculated from the policy audits), school environments (continuous score calculated from the School 
Environmental Audits), child behaviour (proportion of children meeting the PA and sedentary guidelines and proportion meeting the fruit and vegetable consumption guidelines) and subsequent weight status (proportion of children with overweight and obesity) assessed over time. Model fit analyses (e.g., Aikake's and Bayesian Information Criteria) will be used to determine the significance of the impact of the each of the domains of the system, individually and in total, both cross-sectionally and over time.

\section{Discussion and conclusion}

This Healthy Together Victorian and Childhood Obesity research plan outlines a detailed approach for measuring both individual and community changes in obesity and associated risk factors for a population-level communitybased intervention. HTV represents a pioneering application of systems thinking to the primary prevention of chronic disease among children and adults in Victoria, Australia. Employment of an opt-out consent process represents an Australian first for behavioral studies of this type. Other projects suggest an opt-out consent process will result in a response rate in excess of $90 \%$ [51]. In addition, the plan will incorporate these data with broader system measures to better understand system interventions

The employment of a cluster RCT of entire communities to determine effectiveness of the HTV is challenging, although the heterogeneity of systems changes and outcomes between communities will be able to be captured and examined under the second research plan. Additionally, the randomisation of communities in HTV is another strength over other large-scale 'whole of community' obesity/chronic-disease prevention interventions; as other community interventions have instead used a mixture of quasi-experimental research designs or non-randomized comparators [22, 52-54]. Intervention researchers are faced with complex decisions when designing, implementing and evaluating complex interventions to ensure that they that are both acceptable and practical to the people and communities they effect and also to the funding and governing bodies overseeing the projects. The measures for Aim 1 have been selected based on their psychometric properties (reliability and validity) among children and adolescents, but are subject to measurement errors including non-response bias, respondent bias such as social desirability, self-report, as well as respondent memory lapses and coding errors [35]. Although these can never be eradicated, detailed protocols have been developed alongside compulsory training and strict supervision structures for data collection and management to reduce their potential influence. Social desirability is less of an issue in young children than in adults. Regardless of bias, most self-report studies find that people do not meet the recommended levels of fruit and vegetable consumption.
The issue of non-response bias is minimized through the employment of opt-out consent and through the use of electronic data collection to collect data as participants are prompted to complete all question items. A further limitation was that the original HTV study design included areas of more disadvantage and higher prevalence of chronic disease risk factors. This bias may result in results skewed towards higher prevalence of childhood obesity and so may not be generalizable to the wider population.

There is definitive need for large-scale, population-based approaches to prevent obesity/chronic disease globally. Creating a system intervention at this scale is unprecedented and to date methods to understand the possible effectiveness of such an approach have been theoretical or relied on simulation modelling. This protocol represents the first attempt to understand changes in obesity and associated risk factors through HTV using a solution-oriented research paradigm [55] that is based on strong trial study design, but also introduces flexibility to use routine government data in order to understand systems changes.

\section{Competing interest}

The authors declare that they have no competing interests.

\section{Authors' contribution}

CS, LM and SA led the development of the manuscript. All authors provided critical input on all versions of the manuscript and were involved in the design of the study. All authors approved the final version.

\section{Acknowledgements}

Allender is supported by funding from an Australian National Health and Medical Research Council/Australian National Heart Foundation Career Development Fellowship (APP1045836). Strugnell, Millar, Malakellis, Swinburn and Allender are researchers within a NHMRC Centre for Research Excellence in Obesity Policy and Food Systems (APP1041020). Allender and Swinburn are supported by US National Institutes of Health grant titled Systems Science to Guide Whole-ofCommunity Childhood Obesity Interventions (1R01HL115485-01A1). Millar is supported by an Alfred Deakin Early Career Research Fellowship. FNJ is supported by Deakin University. This study was supported by a 2013 Australian National Heart Foundation Vanguard Grant (100259). In addition, we would like to acknowledge the support from the Victorian Department of Health and Human Services, in particular Denise Laughlin, Senior Policy Manager and Atika Farooqui, Senior Epidemiologist and the Victorian Department of Education and Training.

\section{Disclaimer}

The opinion and analysis in this article are those of the author(s) and are not those of the Department of Health and Human Services, the Victorian Government, the Secretary of the Department of Health and Human Services, or the Victorian Minister for Health.

\section{Author details}

${ }^{1}$ World Health Organization's Collaborating Centre for Obesity Prevention, Deakin Population Health, Deakin University, Geelong, Australia. ${ }^{2}$ School of Health and Social Development, Deakin University, Melbourne, Australia. ${ }^{3}$ Formerly Department of Health \& Human Services, Population Health and Prevention Strategy, VIC, Australia. ${ }^{4}$ IMPACT Strategic Research Centre, Deakin University, Geelong, Australia. ${ }^{5}$ Department of Psychiatry, The University of Melbourne, Melbourne, Australia. ${ }^{6}$ Centre for Adolescent Health, Murdoch Children's Research Institute, Melbourne, Australia. ${ }^{7}$ Black Dog Institute, Sydney, Australia. ${ }^{8}$ School of Medicine, Deakin University, Geelong, Australia. ${ }^{9}$ School of Population Health, The University of Auckland, Auckland, New Zealand.

Received: 27 July 2015 Accepted: 18 February 2016 Published online: 25 April 2016 


\section{References}

1. Lobstein T, Baur L, Uauy R. Obesity in children and young people: a crisis in public health. Obes Rev. 2004;5 Suppl 1:4-104.

2. Reilly JJ. Descriptive epidemiology and health consequences of childhood obesity. Best Pract Res Clin Endocrinol Metab. 2005;19(3):327-41.

3. Swinburn BA, Sacks G, Hall KD, McPherson K, Finegood DT, Moodie ML, et al. The global obesity pandemic: shaped by global drivers and local environments. Lancet. 2011;378(9793):804-14. doi:10.1016/S01406736(11)60813-1.

4. Singh AS, Mulder C, Twisk JW, van Mechelen W, Chinapaw MJ. Tracking of childhood overweight into adulthood: a systematic review of the literature. Obes Rev. 2008;9(5):474-88.

5. Wang YC, McPherson K, Marsh T, Gortmaker SL, Brown M. Health and economic burden of the projected obesity trends in the USA and the UK. Lancet. 2011;378(9793):815-25.

6. Waters E, de Silva-Sanigorski A, Hall BJ, Brown T, Campbell KJ, Gao Y, et al. Interventions for preventing obesity in children. Cochrane Database Syst Rev. 2011;12:CD001871. doi:10.1002/14651858.CD001871.pub3.

7. Luckner H, Moss JR, Gericke CA. Effectiveness of interventions to promote healthy weight in general populations of children and adults: a metaanalysis. Eur J Public Health. 2012;22(4):491-7. doi:10.1093/eurpub/ckr141.

8. Doak CM, Visscher TL, Renders CM, Seidell JC. The prevention of overweight and obesity in children and adolescents: a review of interventions and programmes. Obes Rev. 2006;7(1):111-36. doi:10.1111/j.1467-789X.2006.00234.x.

9. Sobol-Goldberg S, Rabinowitz J, Gross R. School-based obesity prevention programs: A meta-analysis of randomized controlled trials. Obesity (Silver Spring). 2013. doi:10.1002/oby.20515

10. Sharma M. International school-based interventions for preventing obesity in children. Obes Rev. 2007;8(2):155-67. doi:10.1111/j.1467-789X. 2006.00268.x.

11. Bleich SN, Segal J, Wu Y, Wilson R, Wang Y. Systematic review of community-based childhood obesity prevention studies. Pediatrics. 2013; 132(1):e201-10. doi:10.1542/peds.2013-0886.

12. Showell NN, Fawole O, Segal J, Wilson RF, Cheskin L, Bleich SN, et al. A systematic review of home-based childhood obesity prevention studies. Pediatrics. 2013;132(1):e193-200. doi:10.1542/peds.2013-0786

13. Vandenbroeck I, Goossens J, Clemens M. Tackling obesities: future choices - building the obesity system map. 2007.

14. Huang TT, Drewnosksi A, Kumanyika S, Glass TA. A systems-oriented multilevel framework for addressing obesity in the 21st century. Prev Chronic Dis. 2009;6(3):A82.

15. Institute of Medicine. Accelerating Progress in Obesity Prevention: Solving the Weight of the Nation. Washington, DC 2012

16. Hunt H, Anderson R, Coelho H, Garside R, Bayliss S, Smith A. The effectiveness of whole of system approaches to prevent obesity. London: National Insitute for Health and Care Excellence; 2011.

17. Victorian Department of Health. Healthy Together Victoria - Frequently Asked Questions (March 2013). In: Department of Health, editor. Melbourne: State Government of Victoria; 2013

18. Department of Health and Human Services Victoria. Creating a healthier Victoria through a whole of systems approach. Melbourne: Victorian Government; 2015.

19. Australian Bureau of Statistics. 3101.0 - Australian Demographic Statistics, Mar 2014. Canberra2014

20. Australian Bureau of Statistics. Census of population and housing: socioeconomic indexes for areas (SEIFA), Australia, 2011. Canberra: Commonwealth of Australia; 2013.

21. de Onis M, Onyango AW, Borghi E, Siyam A, Nishida C, Siekmann J. Development of a WHO growth reference for school-aged children and adolescents. Bull World Health Organ. 2007;85(9):660-7.

22. de Silva-Sanigorski AM, Bell AC, Kremer P, Nichols M, Crellin M, Smith M, et al. Reducing obesity in early childhood: results from Romp \& Chomp, an Australian community-wide intervention program. Am J Clin Nutr. 2010; 91(4):831-40. doi:10.3945/ajcn.2009.28826

23. Sanigorski AM, Bell AC, Kremer PJ, Cuttler R, Swinburn BA. Reducing unhealthy weight gain in children through community capacity-building: results of a quasi-experimental intervention program, Be Active Eat Well. Int J Obes (Lond). 2008;32(7):1060-7. doi:10.1038/ijo.2008.79.

24. Millar L, Kremer P, de Silva-Sanigorski A, McCabe MP, Mavoa H, Moodie M, et al. Reduction in overweight and obesity from a 3-year community-based intervention in Australia: the 'It's Your Move!' project. Obes Rev. 2011;12 Suppl 2:20-8. doi:10.1111/j.1467-789X.2011.00904.x.
25. Commonwealth Scientific Industrial and Research Organisation (CSIRO), University of South Australia. User Guide: 2007 Australian National Children's Nutrition and Physical Activity Survey. University of South Australia. 2008. http://www.health.gov.au/internet/main/publishing.nsf/Content/phd-nutritionchildrens-survey-userguide.

26. Zimmet $P$, Alberti KG, Kaufman F, Tajima N, Silink M, Arslanian S, et al. The metabolic syndrome in children and adolescents - an IDF consensus report. Pediatr Diabetes. 2007;8(5):299-306.

27. McCarthy HD, Jarrett KV, Crawley HF. The development of waist circumference percentiles in British children aged 5.0-16.9 y. Eur J Clin Nutr. 2001;55(10):902-7. doi:10.1038/sj.ejcn.1601240.

28. Wong SL, Leatherdale ST, Manske SR. Reliability and validity of a school-based physical activity questionnaire. Med Sci Sports Exerc. 2006; 38(9):1593-600. doi:10.1249/01.mss.0000227539.58916.35.

29. Helmerhorst HJ, Brage S, Warren J, Besson H, Ekelund U. A systematic review of reliability and objective criterion-related validity of physical activity questionnaires. Int J Behav Nutr Phys Act. 2012;9:103. doi:10.1186/1479-5868-9-103.

30. Card A, Manske S, Mammen G, King M, Gleddie D, Schwartz M. Core Indicators and Measures of Youth Health Physical Activity \& Sedentary Behaviour Module: Indicators and Questions to use with Youth Respondents and/or School Setting Assessment. Newfoundland: Memorial University of Newfoundland; 2012.

31. Tremblay MS, Warburton DE, Janssen I, Paterson DH, Latimer AE, Rhodes RE, et al. New Canadian physical activity guidelines. Appl Physiol Nutr Metab. 2011;36(1):36-46. doi:10.1139/H11-009. 7-58.

32. Tremblay MS, Leblanc AG, Janssen I, Kho ME, Hicks A, Murumets K, et al Canadian sedentary behaviour guidelines for children and youth. Appl Physiol Nutr Metab. 2011;36(1):59-64. doi:10.1139/H11-012. 5-71.

33. Commonwealth Department of Health. Australia's Physical Activity and Sedentary Behaviour Guidelines for Children (5-12 years). Canberra2014.

34. Commonwealth Department of Health. Australia's Physical Activity and Sedentary Behaviour Guidelines for Young People (13-17 Years). Canberra2014.

35. Gibson R. Principles of nutritional assessment. 2nd ed. Oxford: Oxford University Press; 2005.

36. Kolodziejczyk JK, Merchant G, Norman GJ. Reliability and validity of child/ adolescent food frequency questionnaires that assess foods and/or food groups. J Pediatr Gastroenterol Nutr. 2012;55(1):4-13. doi:10.1097/MPG. Ob013e318251550e.

37. National Health \& Medical Research Council. Dietary guidelines for children and adolescents in Australia: incorporating the infant feeding guidelines for health workers. In: NHMRC, editor. Canberra, Aus: Commonwealth of Australia; 2003. p. 444

38. National Health and Medical Research Council. Australian Dietary Guidelines. Canberra: Commonwealth of Australia; 2013.

39. Centres for Disease Control and Prevention. Measuring healthy days: Population assessment of health-related quality of life. Atlanta: Centres for Disease Control and Prevention; 2000

40. Varni JW, Limbers CA, Burwinkle TM. How young can children reliably and validly self-report their health-related quality of life?: an analysis of 8,591 children across age subgroups with the PedsQL 4.0 Generic Core Scales. Health And Qual Of Life Outcomes. 2007:5:1.

41. Eagleson KJ, Justo RN, Ware RS, Johnson SG, Boyle FM. Health-related quality of life and congenital heart disease in Australia. J Paediatr Child Health. 2013;49(10):856-64. doi:10.1111/jpc.12296.

42. Jansen PW, Mensah FK, Clifford S, Nicholson JM, Wake M. Bidirectional associations between overweight and health-related quality of life from 4-11 years: Longitudinal Study of Australian Children. Int J Obes (Lond). 2013;37(10):1307-13. doi:10.1038/ijo.2013.71.

43. Lacy KE, Allender SE, Kremer PJ, de Silva-Sanigorski AM, Millar LM, Moodie $\mathrm{ML}$, et al. Screen time and physical activity behaviours are associated with health-related quality of life in Australian adolescents. Qual Life Res. 2012; 21(6):1085-99. doi:10.1007/s11136-011-0014-5.

44. Hiscock H, Canterford L, Ukoumunne OC, Wake M. Adverse associations of sleep problems in Australian preschoolers: national population study. Pediatrics. 2007;119(1):86-93. doi:10.1542/peds.2006-1757.

45. Varni JW, Burwinkle TM, Seid M, Skarr D. The PedsQL 4.0 as a pediatric population health measure: feasibility, reliability, and validity. Ambul Pediatr. 2003;3(6):329-41.

46. Hoare E, Skouteris H, Fuller-Tyszkiewicz M, Millar L, Allender S. Associations between obesogenic risk factors and depression among adolescents: a systematic review. Obes Rev. 2014;15(1):40-51. doi:10.1111/obr.12069. 
47. Angold A, Costello EJ, Messer SC, Pickles A, Winder F, Silver D. Development of a short questionnaire for use in epidemiological studies of depression in children and adolescents. Int J Methods Psychiatr Res. 1995;5(4):237-49.

48. Jacka FN, Kremer PJ, Leslie ER, Berk M, Patton GC, Toumbourou JW, et al Associations between diet quality and depressed mood in adolescents: results from the Australian Healthy Neighbourhoods Study. Aust N Z J Psychiatry. 2010;44(5):435-42. doi:10.3109/00048670903571598.

49. Mathews L, Kremer P, Sanigorski AM, Simmons A, Nicholls M, Moodie M, et al. Nutrition and physical activity in children and adolescents: Report 1: methods and tools. Melbourne: Department of Human Services; 2009.

50. Rabe-Hesketh S, Skrondal A. Multilevel and longitudinal modeling using Stata. 3rd ed. College Station: Tex:: Stata Press Publication; 2012.

51. Health \& Social Care Information Centre. National Child Measurement Programme: England, 2012/13 school year. London: Government Statistical Service; 2013.

52. Economos CD, Hyatt RR, Must A, Goldberg JP, Kuder J, Naumova EN, et al. Shape Up Somerville two-year results: a community-based environmental change intervention sustains weight reduction in children. Prev Med. 2013;57(4):322-7. doi:10.1016/j.ypmed.2013.06.001.

53. Romon M, Lommez A, Tafflet M, Basdevant A, Oppert JM, Bresson JL, et al. Downward trends in the prevalence of childhood overweight in the setting of 12-year school- and community-based programmes. Public Health Nutr. 2009;12(10):1735-42. doi:10.1017/\$1368980008004278.

54. Jeffery RW. Community programs for obesity prevention: the Minnesota Heart Health Program. Obes Res. 1995;3(2):283s-8s.

55. Robinson TN, Sirard JR. Preventing childhood obesity: a solution-oriented research paradigm. Am J Prev Med. 2005;28(2 Suppl 2):194-201. doi:10.1016/j.amepre.2004.10.030.

56. Parletta N, Cooper P, Petkov J, O'Dea K. Effects of fish oil supplementation on learning and behaviour of children from Australian Indigenous remote community schools: A randomised control trial. Prostaglandins Leukot Essent Fatty Acid. 2013;89(2-3):71-9.

57. Department of Health. Victorian Population Health Survey 2010. Melbourne: State Government of Victoria; 2010. p. 25.

58. Commonwealth Department of Health. Australia's Physical Activity and Sedentary Behaviour Guidelines for Adults (18-64 years). Canberra2014.

59. Vandenbroeck I, Goossens J, Clemens M. Foresight Tackling Obesities: Future Choices - Obesity System Atlas. 2007.

\section{Submit your next manuscript to BioMed Central and we will help you at every step:}

- We accept pre-submission inquiries

- Our selector tool helps you to find the most relevant journal

- We provide round the clock customer support

- Convenient online submission

- Thorough peer review

- Inclusion in PubMed and all major indexing services

- Maximum visibility for your research

Submit your manuscript at www.biomedcentral.com/submit 